\title{
Effects of Probiotic on the Expression of IL-7 Gene and Immune Response to Newcastle Disease Vaccine in Broilers
}

Research Article

Hu L, Shao Y, Jiang N, Gao X, Liu C, Lv X, Zheng S*

Department of Veterinary Medicine, Northeast Agricultural University, Harbin, P.R China.

\section{Abstract}

Probiotics have potential as prevention strategies or therapies for multiple diseases in chickens, such as Newcastle Disease (ND), heat stress, and Coccidiosis, but the mechanism still partially understood. It is an important and warranted issue for further investigation that how probiotics modulated gene expression in disease. In this study, 80 Specific-pathogen-free $(\mathrm{SPF})$ broilers were treated with probiotics, and inoculated La Sota vaccine, then detected the changes of the number of antibody-producing cells $\left(\mathrm{IgA}^{+}, \mathrm{IgM}^{+}\right.$, and $\left.\mathrm{IgG}^{+}\right)$and the expression of IL-7 mRNA in mucosa associated lymphoid tissue (MALT: Harder's gland, cecal tonsils, duodenum and ileum Peyer's patch), and the content of Immunoglobulins (IgA, $\operatorname{IgM}$, and $\mathrm{IgG}$ ) in local humor (tear, trachea fluid, bile and intestinal fluid) by immunohistochemistry staining, RT-qPCR, and IELISA, respectively. Results showed that the contents of $\operatorname{IgA}$, $\operatorname{IgM}$ and $\operatorname{IgG}$ in local humor, the number of $\operatorname{IgA} A^{+}, \operatorname{IgM}^{+}$, and $\mathrm{IgG}^{+}$and the expression of IL-7 mRNA in MALT of inoculated birds were significantly higher than control birds (P $<0.05$ or $\mathrm{P}<0.01$ ) after 7 days post-inoculation $(\mathrm{PI})$, and chickens showed higher immunity response after treated with probiotics. These results indicated that probiotics could enhance the humoral immunity in the respiratory and digestive tracts of chickens, and the immunological response to ND vaccine, and ND vaccine in combining with probiotics will get a better effect on humoral immunity. Both the probiotics and ND vaccine could increase the expression of IL-7 mRNA, and then improve the humoral immunity in the chickens, and the IL-7 maybe one of the ways by which the probiotics improve the humoral immunity.

Keywords: Newcastle Disease; Probiotics; Chickens; Humoral Immunity; IL-7.

\section{Introduction}

Newcastle Disease Virus (NDV) is an economically important and frequently isolated worldwide pathogen whose listed status with OIE marks its importance to both commercial poultry producers and poultry trading [2], as it causes the highly contagious and acute septic infectious diseases of poultry with the typical lesions for respiratory and gastrointestinal mucosal bleeding. As the number of livestock units lost for poultry species, Newcastle Disease (ND) has been ranked as the fourth most important disease [33], and the continuous variation of the NDV pandemic strain contribute to the hard-work in prevention and treatment. Now, vaccination for NDV is primarily by mass application of live-virus vaccines in commercial poultry, but immune protection involves responses that are presently incompletely defined [28]. In terms of ND vaccine, failure reports on the ability of classical ND vaccines to stop spread of disease from many countries, renewed interest in a more complete understanding of the global immune response of poultry to NDV will be critical in developing new control strategies and intervention programs in the future [14].

In the last century, many studies have reported that probiotic play an important role in maintaining the balance of the digestive tract flora, improving the utilization of feed, promoting the absorption of nutrients, and improving the performance of poultry production [11,22], and also in the modulation of immunological, respiratory, inflammation, and gastrointestinal functions [6]. It is available to consumers mainly in the form of dietary supplements and foods. Unlike antibiotics, the probiotics are the green and safe feed additives as for the no residues, nontoxic, and no resistance [20]. Research found that probiotics have effects on the modulation of humoral, cellular and nonspecific

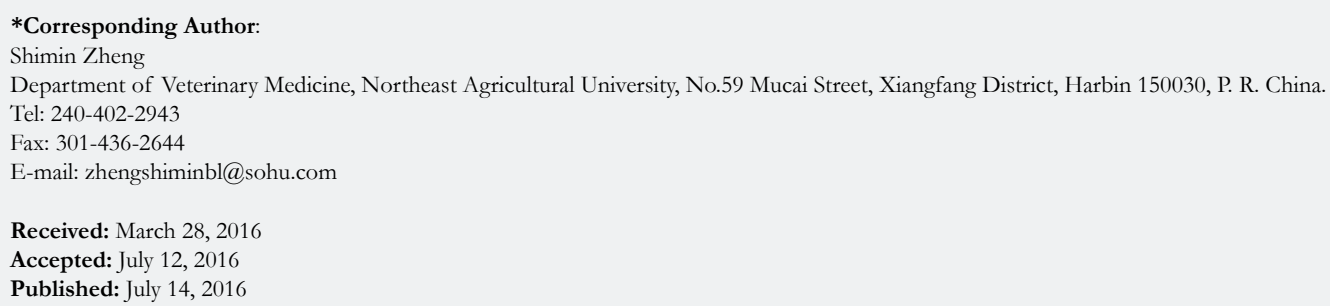

Copyright: Zheng $\mathbf{S}^{\circ}$ 2016. This is an open-access article distributed under the terms of the Creative Commons Attribution License, which permits unrestricted use, distribution and reproduction in any medium, provided the original author and source are credited. 
immunity, especially on immune response in disease models [5]. Understanding the mechanisms is essential to designing probiotics for a specific use.

However, more and more researches are focus on probiotics and immunity in poultry diseases, the mechanism still unclear. Similarly, information related to gene expression in human intestinal cells mediated by the action of probiotics is scarce.

Interleukin 7 (IL-7) is a pluripotent cytokine that plays a critical role in lymphocyte development and homeostasis, it has been suggested as potential immunomodulatory for use in HIV infection [17]. Reported claimed that IL-7 is indispensable to the mature of surface immunoglobulin $\left(\mathrm{sIgM}^{+}\right)$in the conventional cells culture, and cell culture with IL-7 balance the generated from B cells by controlling cell death. IL-7 receptor-deficient mice are always along with the absence of $\gamma \delta$ TCR and Intestinal intraepithelial lymphocytes (IEL), and their $\operatorname{IgA}^{+}$plasma cells was significantly decreased in intestinal mucosa, the secretion of the $\operatorname{IgA}$ and the response to antigen's stimulation of $\operatorname{IgA}$ also declined [18]. In normal mice, IL-7 have a stimulating effect on the B cells of spleen, lymph nodes and bone marrow, so it often used to induce $\mathrm{B}$ cell in vitro [21]. People also found the IL-7 pathway is essential to immune system development and maintenance in physiological conditions [19]. Recently, more and more reports on the IL-7 application and clinical treatment, IL-7 can effectively elicit an immune reconstruction in a variety of lymphopenia's model, and injected IL-7 can accelerate recovering the number of $\mathrm{CD}^{+}$and $\mathrm{CD}^{+} \mathrm{T}$ cells in the spleen and lymph node [16], and it reported that autologous tumor vaccine modified with NDV strain LX/(IL-7) could promote the antitumor immune responses mediated by $\mathrm{CD} 8^{+} \mathrm{T}$ cells and significantly improve the efficacy of the Autologous tumor vaccine modified with nonlytic Newcastle disease virus (ATV-NDV) [36]. However, limited studies have been conducted to the relationship between IL-7 and probiotics, and evaluate the potential of IL-7 expressing ND vaccine to induce anti-NDV immune response in chickens with probiotics protection efficacy. Consequently, a rapid, sensitive, and specific RT-qPCR assay was designed for the detection of IL-7 gene with SYBR Green, try to clarify the effects of probiotic on the expression of IL-7 mRNA and immune response in mucosa associated lymphoid tissue (MALT) of chickens to ND vaccine. The aim of this study was to reveal the effects and mechanism of probiotics on humoral immunity and response to ND vaccine, and lay the foundation for the further research and utility of probiotics in poultry.

\section{Materials and Methods}

\section{Chickens, probiotics, and ND vaccine}

Specific pathogen-free (SPF) Avain broilers ( $\mathrm{n}=80$, one-day-old) were purchased from and fed in SPF Laboratory Animal Center of Harbin Veterinary Research Institute, Chinese Academy of Agricultural Sciences (CAAS), Harbin, China. Probiotics were provided by HUAERKANG Biotechnology Co. Ltd, Jinan, China, which is mainly contains of Bacillus subtilis, Bacillus licheniformis, Lactobacillus, Bifidobacterium, yeast, etc., as well as some enzymes like cellulase, hemicellulase and pectinase. Numbers of total and viable bacteria is more than 20 billion per gram, and (Total) enzyme activity is more than 1,000 u/g. LaSota vaccine (IV strain) were from First Biological Factory of Harbin Pharmaceutical Group, Harbin, China.

\section{Experimental design}

Random allocation was taken to averagely divide the broilers into four groups named as Control group (C), Probiotics treated group $(\mathrm{P})$, ND vaccine inoculated group $(\mathrm{N})$, and Probiotics treated and ND vaccine inoculated group (S). The schedule of all treatment was presented in Table 1.

The MALT (Harder's gland, cecal tonsils, duodenum Peyer's patch, and ileum Peyer's patch) and local humor (tear, trachea fluid, bile and intestinal fluid) were collected from three birds per group on days $0,7,14,28$ and 42 post-inoculation (PI).

\section{Indirect Enzyme-linked Immunosorbent assay (IELISA)}

Collected tear, trachea fluid, bile and intestinal fluid were diluted by PBS (0.05M pH9.6) according to 1:10, but tear according to $1: 50$, and then add to the 96-well polystyrene microtiter plate, $200 \mu \mathrm{l}$ per hole. Here, the dilution for rabbit anti-chicken whole serum was 1:200 as primary antibodies, and the dilution for HRPlabeled Goat Anti-Rabbit IgG conjugate was 1:500 as second antibodies. However, 100 $\mu$ l TMB (tetramethylbenzidine, Sigma,

Table 1. Schedule of probiotics treatment and ND vaccine inoculation.

\begin{tabular}{|c|c|c|c|c|}
\hline \multirow{2}{*}{ Group } & \multirow{2}{*}{ Number of chickens } & \multicolumn{3}{|c|}{ Treatment } \\
\cline { 3 - 5 } & & Probiotics $^{\mathbf{1}}$ & ND vaccine $^{2}$ & PBS $^{3}$ \\
\hline $\mathrm{C}^{4}$ & 20 & - & - & + \\
\hline $\mathrm{P}^{5}$ & 20 & + & - & - \\
\hline $\mathrm{N}^{6}$ & 20 & - & + & - \\
\hline $\mathrm{S}^{7}$ & 20 & + & + & - \\
\hline
\end{tabular}

\footnotetext{
${ }^{1}$ Probiotics was fed at $1,2,3,7,8,9,13,14$, and 15 day, respectively, one time per day, at the manufacture's recommend dosage (200g per kilogram of drink water).

${ }^{2} \mathrm{ND}$ vaccine was given by eye and nasal drop at 10-day-old (fist inoculation), 106 embryo infective doses per bird, after dilution in nutrient broth. Second inoculation was treated double dose at 21-day-old.

${ }^{3}$ PBS, Phosphate-buffered saline was administered the same doses with probiotics and vaccine by the same route at the same day.

${ }^{4} \mathrm{C}$, Control group.

${ }^{5} \mathrm{P}$, Probiotics treated group.

${ }^{6} \mathrm{~N}$, ND vaccine inoculated group.

${ }^{7} \mathrm{~S}$, Probiotics treated and ND vaccine inoculated group.
} 
USA) as the color-developing agent was added to each hole. As soon as the chromogenic reaction was terminated, the OD (optical density) value was counted on $450 \mathrm{~nm}$ by Universal Microplate Spectrophotometer (Molecular Devices, USA), and calculated the average of three holes of each sample.

Immunohistochemistry streptavidin-peroxidase (IHC - SP) staining

The procedure of IHC - SP staining was performed by the immunohistochemical kit (ZSGB-Bio, Beijing, China). The dilution for rabbit anti-chicken polyclonal antibody (Prepared in our laboratory) was $1: 100$ as primary antibodies, and the dilution for HRP-labeled Goat Anti-Rabbit IgG $(\mathrm{H}+\mathrm{L})$ was 1:500 as second antibodies. PBS replaced antibody in the negative control group. In addition, the TMB is for color reactions, and the apparent brown color observed under a light microscope indicated positive staining of the bound toxin. Finally, the number of $\mathrm{IgA}^{+}, \mathrm{IgM}^{+}$, and $\mathrm{IgG}^{+}$in MALT were enumerated with pointcounting method by H600L Microscopic pathological imaging system (Nikon, Japan).

\section{Real-time Quantitative PCR (RT-qPCR)}

Totals RNA of MALT were extracted by using a Trizol Reagent (Invitrogen, USA) as recommended by the manufacturer. The qualities of RNA were analyzed by the electrophoresis 1.0\% agarose gel. Moreover, the concentrations of RNA were quantified using UV Spectrophotometer (APEL, Japan) at $260 \mathrm{~nm}$ and 280 $\mathrm{nm}\left(\mathrm{OD}_{260} / \mathrm{OD}_{280}=1.8\right)$. According to the specific sequences of chicken IL-7 and $\beta$-actin in Genbank, primers were synthesized by Invitrogen (USA). Details of the primers are given in Table 2. Complementary DNA (cDNA) was synthesized in a volume of $25 \mu \mathrm{l}$ with Moloney Murine Leukemia Virus (M-MLV) Reverse transcriptase (Promega, USA) according to the manufacturer's protocol. IL-7 and $\beta$-actin was amplified using Taq DNA Polymerase (Promega, USA) according to the manufacturer's protocol. The resulting PCR products were cloned into pMD18-T Vector (TakaRa, Dalian, China) and propagated in competent Escherichia coli DH5 $\alpha$ cells (Life Technologies, USA), according to the manufacturer's instructions. Plasmid DNA was purified on columns with a StarPrep Plasmid Miniprep Kit (GenStar Bio Solutions, Beijing, China) and the concentrations were measured by UV spectrophotometer. 10 fold dilutions of plasmid DNA were used to construct the standard curve. RT-qPCR reactions were performed in Light Cycler 2.0 (Roche Diagnostics, USA) with a total reaction volume of $20 \mu$, containing $10 \mu$ l Platinum ${ }^{\circledR}$ $\mathrm{SYBR}^{\circledR}$ Green qPCR SuperMix-UDG (Invitrogen, USA), 2.0 $\mu$ l plasmid DNA, $0.8 \mu \mathrm{l}(10 \mu \mathrm{moL} / \mathrm{L})$ of each primers, and $1.0 \mu \mathrm{l}$ Bovine Serum Albumin (BSA; Thermo Fisher, USA). Each amplification was performed in triplicate wells. The temperaturetime profile was pre-denaturation at $95^{\circ} \mathrm{C}$ for 30 s followed by 45 cycles of $95^{\circ} \mathrm{C}$ for $5 \mathrm{~s}, 60^{\circ} \mathrm{C}$ for $20 \mathrm{~s}$, and a final extension cycle at $72^{\circ} \mathrm{C}$ for 10 s.

\section{Statistical analysis}

The data of RT-qPCR were recorded and analyzed by the Light Cycler software 4.0. Copy number of target genes (relative to $\beta$-actin) was defined by $2^{-\Delta \Delta C t}[7]$, where $\Delta \Delta C t=\Delta C t$ [sample]$\Delta C t$ [calibrator $]=\left(C t_{T G F-\beta 1}-C t_{\beta-a c t i n}\right)$ [sample] $-\left(C t_{T G F-\beta 1}-C t_{\beta-a c t i n}\right)$ [calibrator]. All of the statistical analyses were performed using SPSS 17.0. The Student's $t$-test was used to determine significant differences between change values of the six time points post infection. A value of $\mathrm{p}<0.05$ was considered to be significant. Statistical analysis was carried out using Prism 5.0 (GraphPad Software).

\section{Results}

\section{Changes of IgA, IgM, and IgG in local humor by IELISA}

The contents of $\operatorname{IgA}, \operatorname{IgM}, \operatorname{IgG}$ in the tear, trachea fluid, bile and intestinal fluid of $\mathrm{P}, \mathrm{N}$ and $\mathrm{S}$ showed higher than $\mathrm{C}$ at the same time point $\mathrm{PI}$, and $\mathrm{S}$ were higher than $\mathrm{N}, \mathrm{N}$ were higher than $\mathrm{P}$ (Figure 1, 2). And the contents of $\operatorname{IgA}$, IgM, and $\operatorname{IgG}$ in these humors are increased before 7 day PI, and then recovered to normal. There was no significant difference $(\mathrm{P}>0.05)$ in the contents of $\operatorname{IgA}, \operatorname{IgM}$, and $\operatorname{IgG}$ in the tear and bile between $\mathrm{P}$ and $\mathrm{C}$ among 7 to 42 day PI, while the contents of $\operatorname{IgA}, \operatorname{IgM}$, and $\mathrm{IgG}$ in intestinal fluid, and the contents of $\operatorname{IgA}$ in trachea fluid of $\mathrm{P}$ showed a very significantly higher $(\mathrm{P}<0.01)$ than $\mathrm{C}$ among 7 to 14 day PI. In the comparison of $\mathrm{P}$ and $\mathrm{S}, \mathrm{S}$ was higher than $\mathrm{P}$, the significant difference occurred in the tear $(\operatorname{Ig} A)$ at 14 day PI $(\mathrm{P}<0.01)$, in the trachea fluid $(\operatorname{IgM})$ at 7 and 28 day PI $(\mathrm{P}<0.01$ or $\mathrm{P}<0.05)$, in bile (IgA, IgG) at 7 to 14 day PI $(\mathrm{P}<0.01)$, and in the intestinal fluid (IgA, $\operatorname{IgM}, \operatorname{IgG})$ at 7 to 14 day PI $(\mathrm{P}<0.01)$. As for $\mathrm{P}$ and $\mathrm{N}$, the contents of $\operatorname{IgA}, \operatorname{IgM}$, and $\operatorname{IgG}$ in all detected humors in $\mathrm{N}$ were very higher than $\mathrm{P}$ at 0 day $\mathrm{PI}$, and the same results still found in the bile $(\operatorname{IgG})$ and intestinal fluid $(\operatorname{IgA})$ at 14 day PI. In addition, there was a significantly difference between $\mathrm{N}$ and $\mathrm{S}$ in the contents of $\operatorname{IgA}$ in the tear, trachea fluid, bile and intestinal fluid at 0 day, and it also showed the same results in tear and bile at 14 day, 7 and 42 day PI, respectively. The contents of $\mathrm{IgM}$ in intestinal fluid of $\mathrm{S}$ were significantly higher than $\mathrm{N}$ at 0 to 14 day PI. The contents of IgG in bile and intestinal fluid showed a significant difference between $\mathrm{N}$ and $\mathrm{S}$ at 0 to 14 day PI $(\mathrm{P}<0.01)$.

\section{Changes of $\operatorname{IgA}^{+}, \operatorname{IgM}^{+}$, and $\operatorname{IgG}^{+}$in MALT by IHC - SP staining}

From the Figure 3 and 4 , the numbers of $\operatorname{IgA}{ }^{+}, \operatorname{IgM}^{+}$, and $\operatorname{IgG}^{+}$ in Harder's gland, cecal tonsils, duodenum Peyer's patch and ileum

Table 2. Sequence of primers used in this study.

\begin{tabular}{|c|c|c|}
\hline Primers & Sequences & Accession No./ Amplicon size \\
\hline IL-7(F) & TCTATCTTTCGGGTTCTGCCA & AM931037 / 135bp \\
\hline IL-7(B) & CATGACATCGAAGAGCTGGTA & \\
\hline$\beta$-actin(F) & TGAAGCCCAGAGCAAAAGAGGTAT & AF294323 / 135bp \\
\hline$\beta$-actin(B) & TGCTCCTCAGGGCTACTCTC & \\
\hline
\end{tabular}


Figure 1. Contents of IgA, IgM, and IgG in the tear (A, B, C) and trachea fluid (D, E, F) of experimental chickens, respectively. Data are mean \pm SD of three chickens per group. Adjacent letters indicates significantly different between any two groups at the same time point $(P<0.05)$, with interval letter indicates very significantly difference at $P<0.01$; the same letters and no letters means that no significant different $(P>0.05)$.
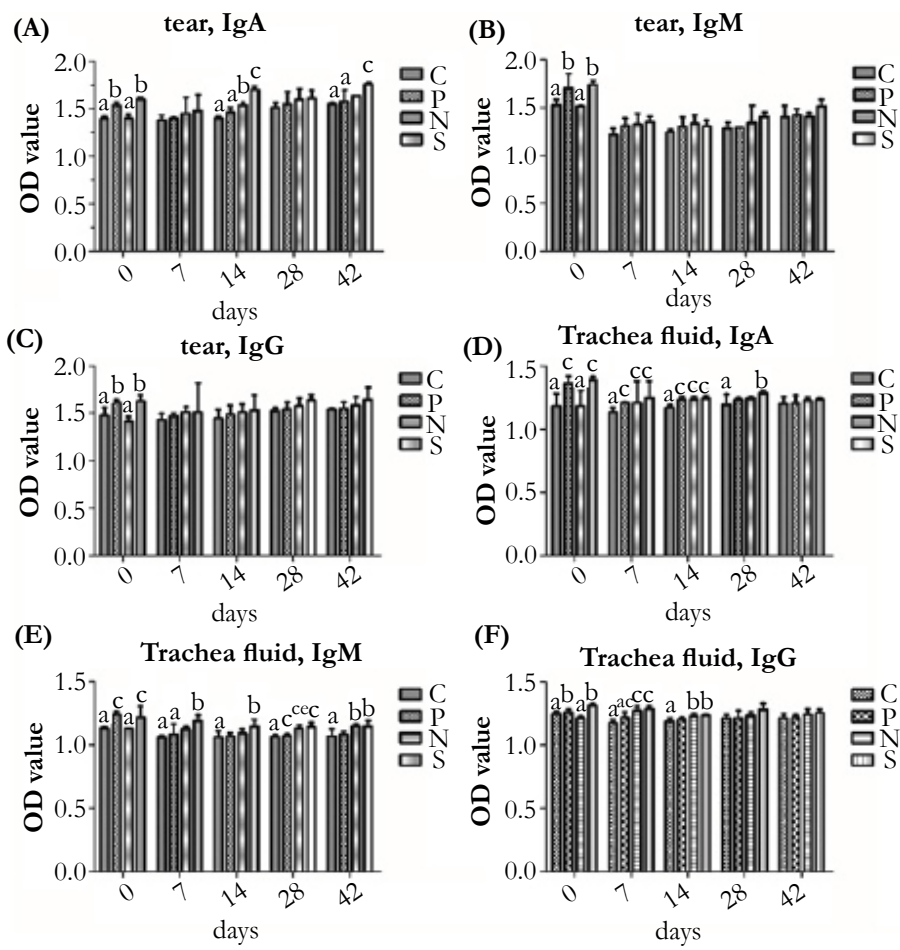

Figure 2. Contents of IgA, IgM, and IgG in the bile (G, H, I) and intestinal fluid (J, K, L) of experimental chickens, respectively. Data are mean \pm SD of three chickens per group. Adjacent letters indicates significantly different between any two groups at the same time point $(P<0.05)$, with interval letter indicates very significantly difference at $P<0.01 ;$ the same letters and no letters means that no significant different $(P>0.05)$.
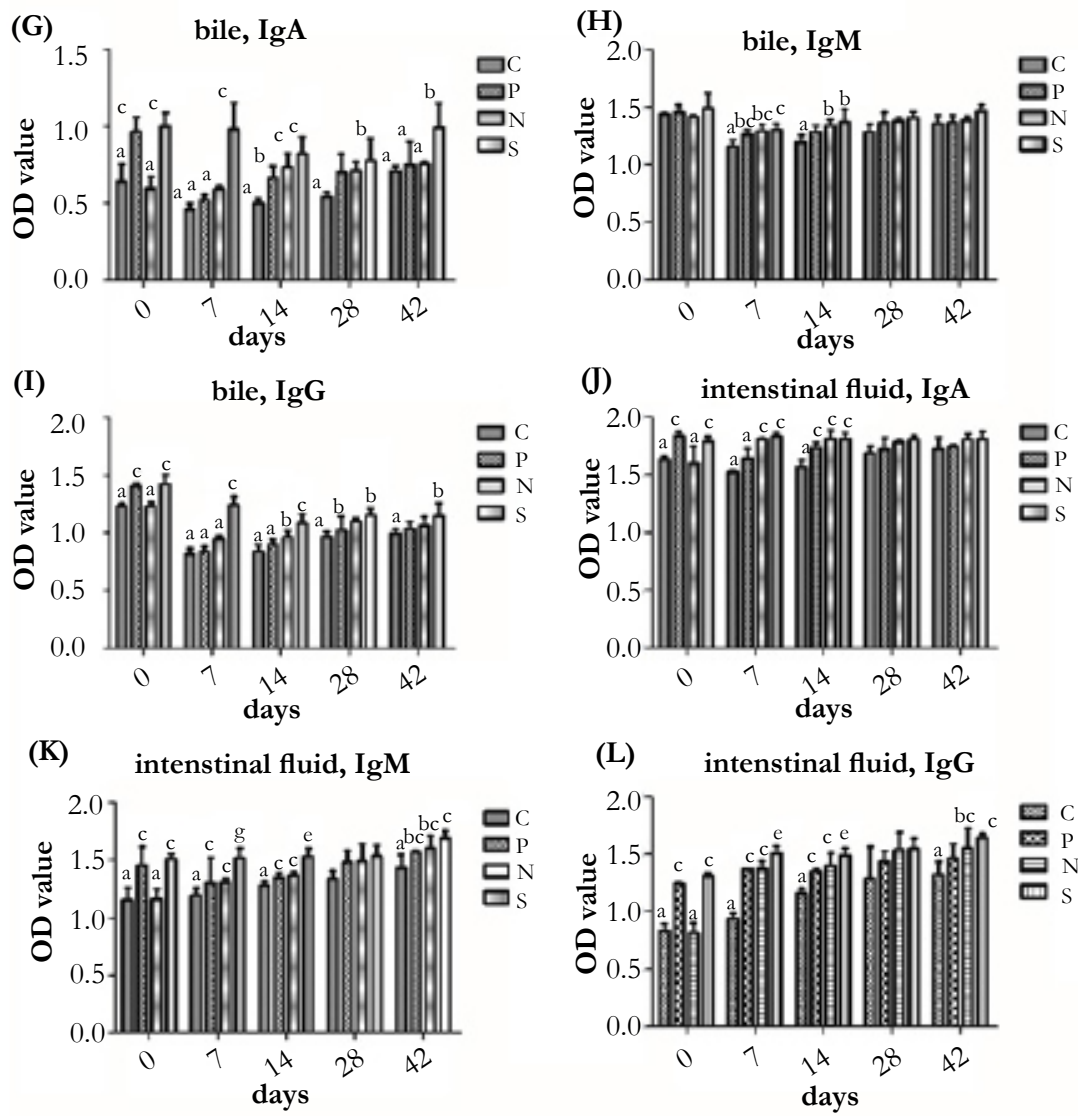
Figure 3. Numbers of $\operatorname{IgA}^{+}, \operatorname{IgM}^{+}$, and $\mathrm{IgG}^{+}$in Harder's gland (A, B, C) and cecal tonsils (D, E, F) of experimental chickens, respectively. Data are mean \pm SD of three chickens per group. Adjacent letters indicates significantly different between any two groups at the same time point $(P<0.05)$, with interval letter indicates very significantly difference at $P<0.01 ;$ the same letters and no letters means that no significant different $(P>0.05)$.
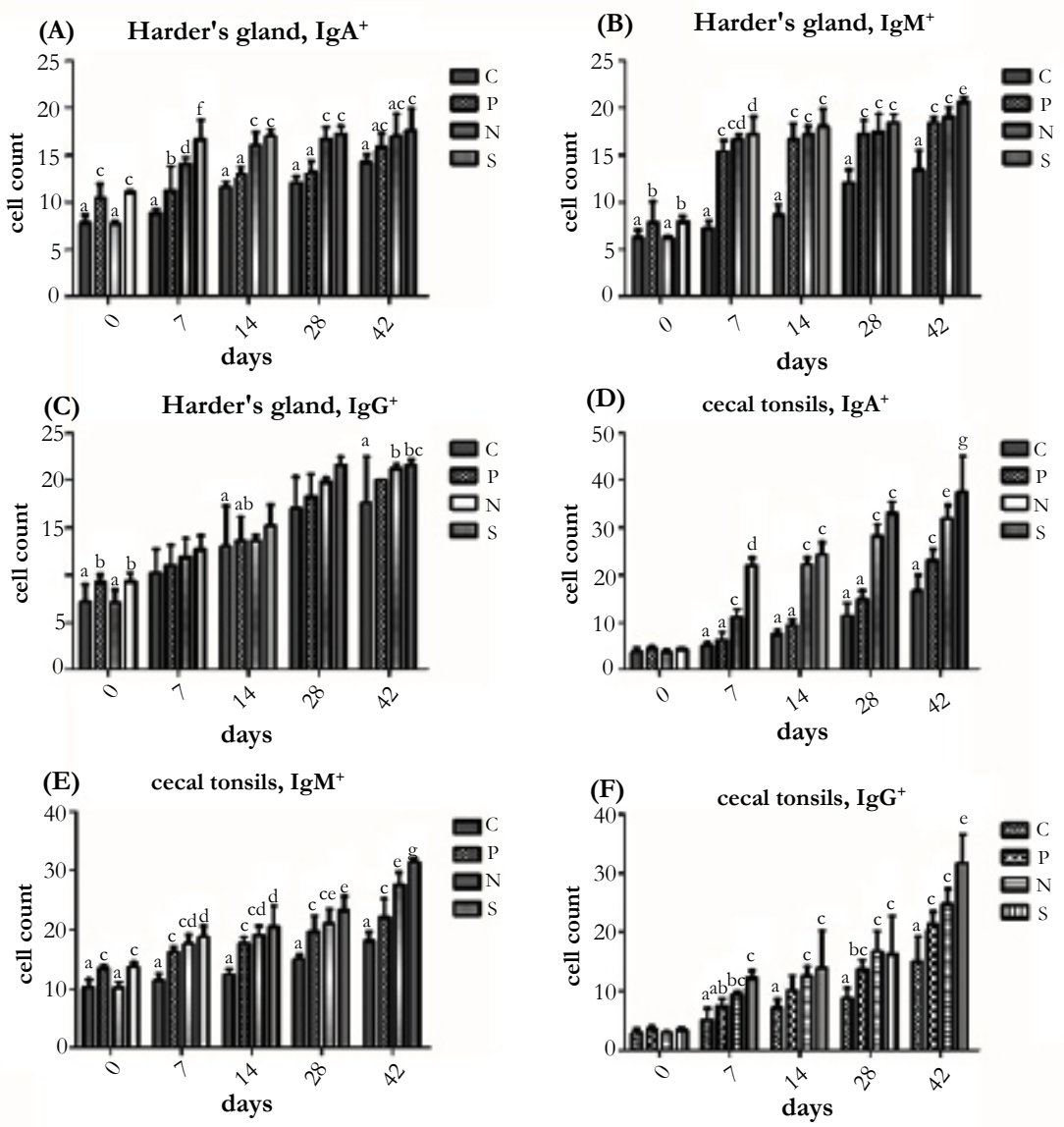

Figure 4. Numbers of $\mathrm{IgA}^{+}, \mathrm{IgM}^{+}$, and $\mathrm{IgG}^{+}$in duodenum Peyer's patch $(\mathrm{G}, \mathrm{H}, \mathrm{I})$ and ileum Peyer's patch (J, K, L) of experimental chickens, respectively. Data are mean \pm SD of three chickens per group Adjacent letters indicates significantly different between any two groups at the same time point $(P<0.05)$, with interval letter indicates very significantly difference at $\mathrm{P}<0.01$; the same letters and no letters means that no significant different $(P>0.05)$.
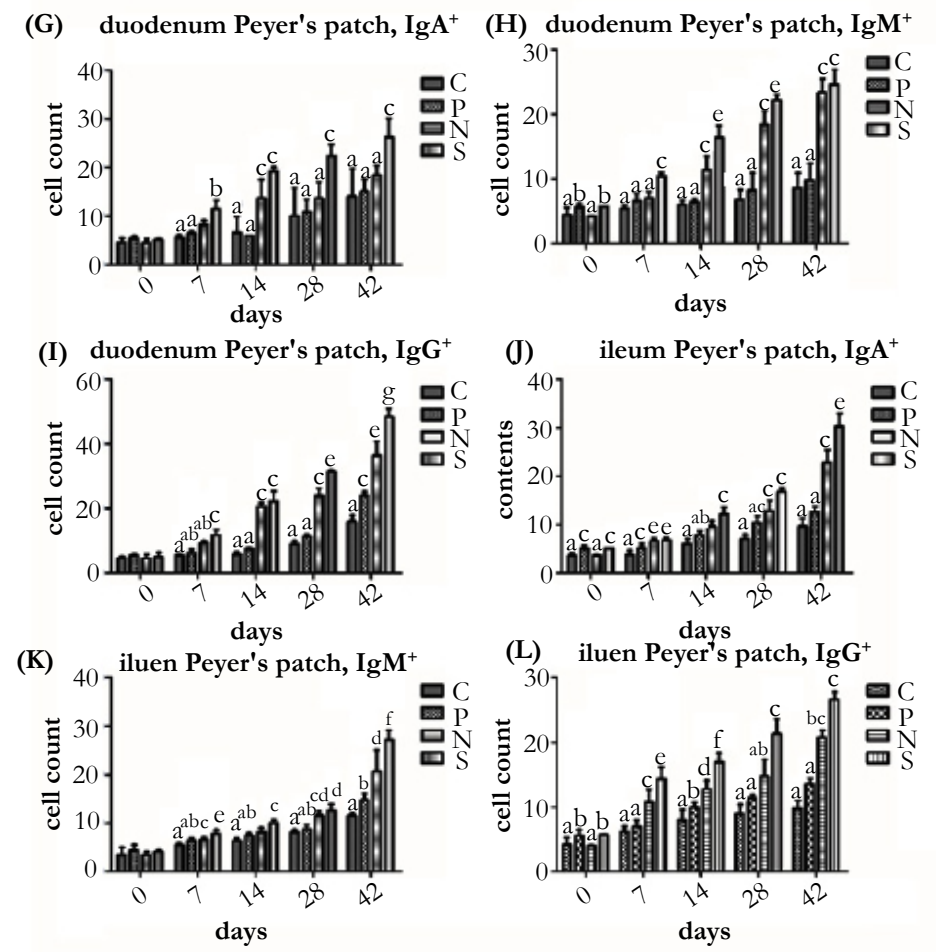
Figure 5. Establishment of RT-qPCR to detect the expression of IL-7 mRNA in MALT of experimental chickens. (A), (B), (C) were represent the amplication, standard, and melting curve of pMD18-T-IL-7 plasmid, respectively. (D), (E), (F) were represent the amplication, standard, and melting curve of pMD18-T- $\beta$-actin plasmid, respectively. R2 values for IL-7 and $\beta$-actin were 0.999 and 0.998 , respectively. And the slopes of the standard curve for IL-7 and $\beta$-actin were -3.217 and -3.358 , respectively.

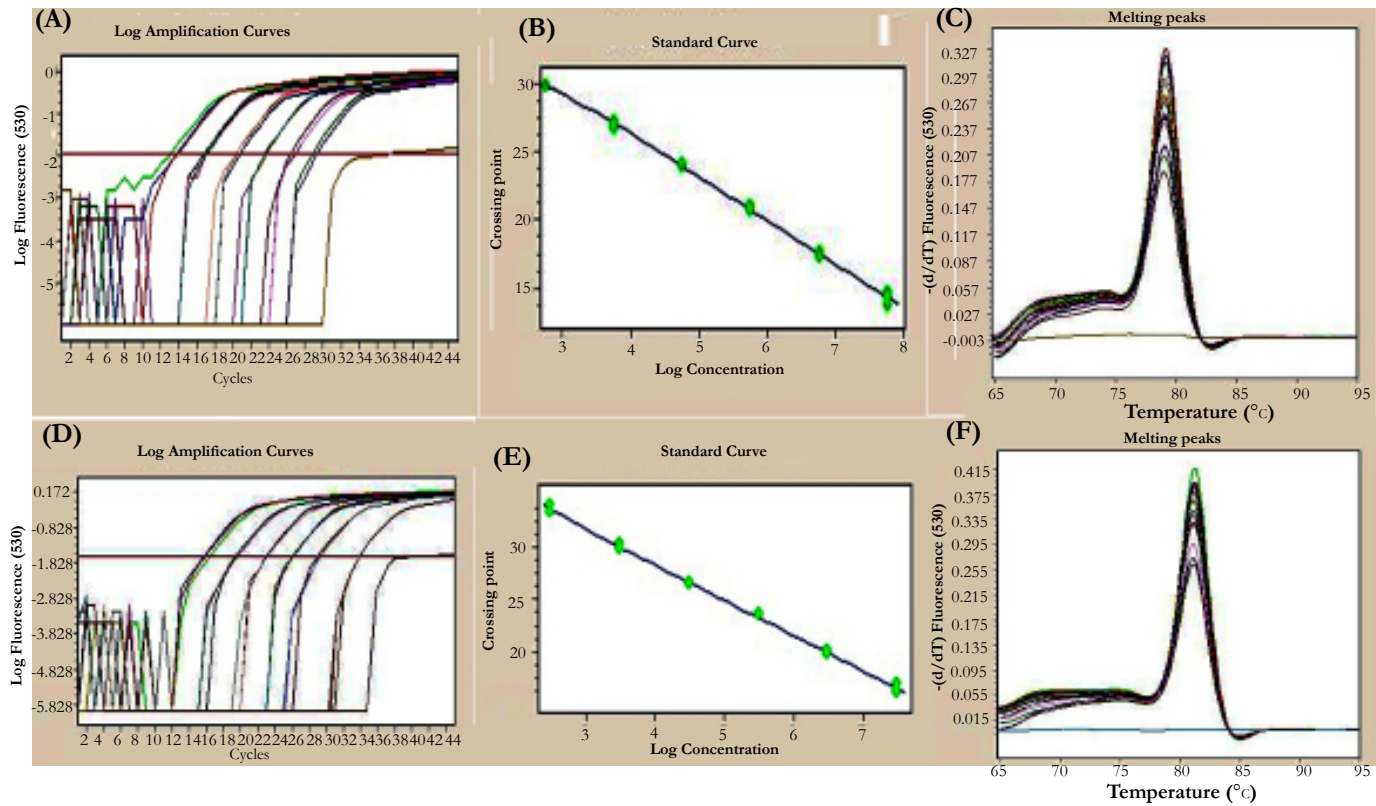

Figure 6. Expression of IL-7 mRNA in Harder's gland (A), cecal tonsils (B), duodenum Peyer's patch (C), and ileum Peyer's patch (D) of experimental chickens. Data are mean \pm SD of three chickens per group. Adjacent letters indicates significantly different between any two groups at the same time point $(P<0.05)$, with interval letter indicates very significantly difference at $\mathbf{P}<0.01$; the same letters and no letters means that no significant different $(P>0.05)$.

(A)
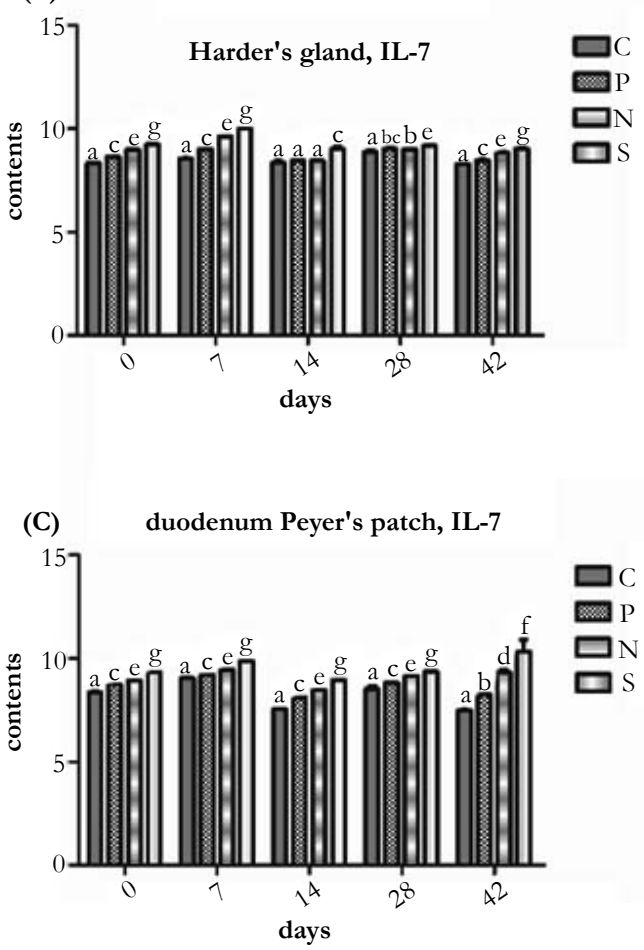

Peyer's patch in $\mathrm{P}, \mathrm{N}$, and $\mathrm{S}$ were higher than that of the $\mathrm{C}$ at the same time point $\mathrm{PI}$, and $\mathrm{S}$ showed higher than $\mathrm{N}, \mathrm{N}$ were higher than $\mathrm{P}$, as well. In the comparison of $\mathrm{P}$ and $\mathrm{C}$ in these immune tissues, the numbers of $\operatorname{IgA}^{+}$in Harder's gland and ileum Peyer's patch of $\mathrm{P}$ has a significantly higher than $\mathrm{C}$ at 0 and 7 day PI (P $<0.01$ or $\mathrm{P}<0.05)$, and the numbers of $\mathrm{IgM}^{+}$in Harder's gland and cecal tonsils showed significantly difference among 0 to 42 day PI $(\mathrm{P}<0.01$ or $\mathrm{P}<0.05)$, while the numbers of $\mathrm{IgG}^{+}$found
(B)

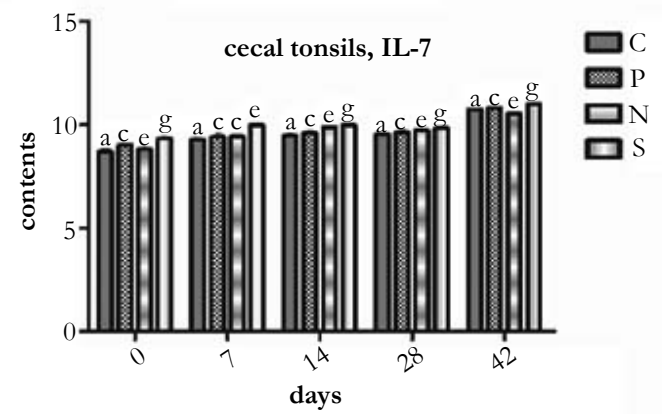

(D)

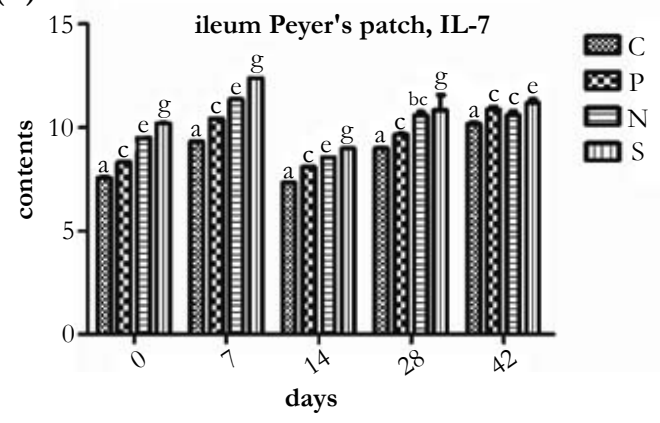

the same results in Harder's gland at 0 day $(\mathrm{P}<0.05)$, in cecal tonsils at 28 day $(\mathrm{P}<0.01)$, in duodenum Peyer's patch at 42 day $(\mathrm{P}<0.01)$, and in ileum Peyer's patch at 14 day $(\mathrm{P}<0.05)$, respectively. By enumerated the numbers of $\operatorname{IgA}^{+}, \operatorname{IgM}^{+}$, and $\mathrm{IgG}^{+}$in these immune tissues, the significant difference between $\mathrm{P}$ and $\mathrm{S}$ occurred after 7 day PI. What's more, in the comparison the numbers of $\operatorname{IgA}^{+}$in these immune tissues of $\mathrm{P}$ and $\mathrm{N}$, the significant difference between two groups occurred after 7 day 
PI, and there was a significant different the two group birds in the $\mathrm{IgM}^{+}$and $\mathrm{IgG}^{+}$of duodenum and ileum Peyer's patch $(\mathrm{P}<$ 0.01 or $\mathrm{P}<0.05)$. Additionally, the number of $\mathrm{IgA}^{+}$in Harder's gland of $\mathrm{S}$ were higher than that of $\mathrm{N}$ from 0 to 7 day PI, and it showed same results in cecal tonsils and Peyer's patch at 42 day PI $(\mathrm{P}<0.01)$; there was a significantly different between $\mathrm{S}$ and $\mathrm{N}$ for the numbers of $\mathrm{IgM}^{+}$in Harder's gland and cecal tonsils at 42 day PI $(\mathrm{P}<0.01)$, and the same results found in duodenum and ileum Peyer's patch at 1 to 28 day, 7 and 42 day PI, respectively. As for the number of $\mathrm{IgG}^{+}, \mathrm{S}$ had a significant higher than $\mathrm{P}$ in duodenum and ileum Peyer's patch after 28 day PI.

\section{Expression of IL-7 mRNA in MALT by RT-qPCR}

The comparative analysis of nucleotide homology between IL-7 and $\beta$-actin sequences which has been determinated by Takara (Beijing, China) and results are 100\% and $99.5 \%$ in comparison of the sequence that has been published in GenBank, respectively. Tenfold IL-7 and $\beta$-actin standard dilutions $\left(10^{-3}, 10^{-4}, 10^{-5}, 10^{-}\right.$ ${ }^{6}, 10^{-7}, 10^{-8}$ ) amplified by RT-qPCR (Figure 5A and 5D). In our standard curves (Figure 5B and 5D), R2 values for IL-7 and $\beta$-actin were 0.999 and 0.998 , respectively, which were greater than 0.99. And the slopes of the standard curve for IL-7 and $\beta$-actin were -3.217 and -3.358 , respectively, which also showed a high credibility. The melting curves of IL-7 and $\beta$-actin formed a single peak at $79.6^{\circ} \mathrm{C}$ and $81.7^{\circ} \mathrm{C}$, respectively (Figure $5 \mathrm{C}$ and $5 \mathrm{~F})$. In addition, all negative control were flat, indicated that the primers of IL-7 and $\beta$-actin were specificity for this study.

As results illustrated in Figure 6, the IL-7 mRNA expression in Harder's gland, cecal tonsil, duodenum Peyer's patch, and ileum Peyer's patch of all experimental group (P, N, and S) are higher than $\mathrm{C}$ at the same time point, and it showed the low expression in these immune tissues of all experimental groups at 14 day PI, in comparison with other days PI. In the view of $C$ and $\mathrm{P}$, the IL-7 mRNA expression of $\mathrm{P}$ in these immune tissues had a significantly higher than $\mathrm{P}$ at 0 to 42 day $\mathrm{PI}(\mathrm{P}<0.01$ or $\mathrm{P}<0.05)$. In the comparison of $\mathrm{P}$ and $\mathrm{N}$, the IL-7 mRNA expression in these immune tissues showed significant difference between two groups among 0 to 42 day $\mathrm{PI}(\mathrm{P}<0.01$ or $\mathrm{P}<0.05)$, excluding 28 day PI in Harder's gland (compare P and N), 42 day PI in ileum Peyer's patch (compare P and N), and 28 day PI in ileum Peyer's patch (compare $\mathrm{N}$ and $\mathrm{S}$ ), that the three comparison data showed no significantly deference $(\mathrm{P}>0.05)$.

\section{Discussion}

Mucosal immune system (MIS), as the first barrier to protect from pathogenic microorganisms for poultry, can produce both humor immunity and cell immunity by antigen, but the former is dominated. It's reported that more than $95 \%$ of the poultry's infections occur in or invaded through the mucosal [25]. IgA, IgM, and $\mathrm{IgG}$ antibodies are produced as part of the immune response in chickens [10]. It was found that Peyer's patches are a highly enriched source of cells which have the potential to proliferate and differentiate into IgA-producing immunocytes. Cecal tonsil as an important source of antibodies, not only does it involve in the production of antibodies, but also in cell-mediated immune (CMI) response, and has a local immunity effects on intestinal bacteria and other antigenic material. Harder's gland is a specific immune tissue in chicken's eye ground, which plays a significant role on local immunity. When chickens infected with vaccine, Harder's gland generated and improved immune response to the vaccine with the independent of maternal antibody interference [31].

In this study, probiotic contains of variety of living bacteria and enzymes, it was found that probiotic can not only improve the humor immunity of chickens, but also enhanced the humor immunity response to ND vaccine, when used in combination with ND vaccine it is recognized as the more effective treatment for improving humor immunity. These results are in consistent with the previously reports. People found that probiotics initially planting on the gut play a pivotal on stimulating the development of immunity system. It have a wide range of enhancing immune function, such as activating the immune cells, increasing the number of $\mathrm{T}$ and $\mathrm{B}$ cells, promoting the proliferation and maturation of $\mathrm{T}$ and $\mathrm{B}$ cells, enhancing the capability of immune recognition, and inducing cytokines production, moreover, it can strengthen the immune defense by lymphocyte recirculation to activate the whole immune system in host [8, 24]. Lactobacillusbased probiotics have been shown to improve humoral immunity in chicken's response to live ND vaccines during heat stress [30]. In weaned rabbits study, Fed-bacillus licheniformis had an increasing of humoral immunity and the effect of vaccine vaccinated with Bacillus licheniformis was better than only vaccine in weaned rabbits [13].

As a heterologous antigen, the vaccine recognized and processed to Th cells by antigen presenting cell (APC), and activated Th cells to secrete various cytokines, and then these cytokines combine with B-cell receptor (BCR) to promote the production of antigen for humor immunity. Furthermore, B cells can recognize the antigen, and differentiate and mature by Th cells' assist for humor immunity. It was reported that probiotics can significantly improve the level of Igs in serum and gut in chickens inoculated with tetanus toxoid and Clostridium perfringens $\alpha$-type vaccines [8]. Moreover, probiotics can increase the level of $\mathrm{IgG}$ in serum of baby for $\beta$-type haemophilus influenza vaccine [15]. However, the dominant antibody isotype of the mucosal immune system is $\operatorname{IgA}$, especially $\operatorname{sg} \mathrm{A}$, so we also found that the contents of $\operatorname{IgA}$ increased more than $\operatorname{IgM}$ and $\operatorname{IgG}$, even the three Igs all increased after chicken fed with probiotics and inoculated with ND vaccine. Study showed that the contents of $\operatorname{IgA}$ increased rapidly in the tear, Harder's gland and tracheal liquid after chickens vaccinated with ND vaccine by nasal drops, especially in the tear at 2 weeks after vaccinated [34]. Moreover, sIgA expressed high level in intranasal, trachea, bronchi and bronchioles mucus after inoculated with a lethal dose of influenza virus for mice, which demonstrated that sIgA participate in the defense against influenza virus in the upper respiratory tract [1]. Study on the cold stress cause the change of the change of immune function in chicken intestinal, demonstrated that the expression levels of $\operatorname{IgM}, \operatorname{IgA}$, IgG, and IL-7 had an increased tendency in the small intestine of broilers following acute and chronic cold [35]. After CD4 ${ }^{+}$ T-deficient mice inoculated with Formalin inactivated influenza virus $\mathrm{A} / \mathrm{PR} 8 / 34$, the contents of $\operatorname{IgG}$ and $\operatorname{IgA}$ in serum and $\operatorname{sg} \mathrm{A}$ in mucosal secretions were high increased. However, recently research claimed that antibodies remain the primary mechanism contribute to the protection against virulent NDV in the CMI detection following live NDV, and CMI are still an important factor to be considered in the face of field challenge [14]. 
Here we showed that the expression of IL-7 mRNA in Harder's gland, cecal tonsil, duodenum and ileum Peyer's patch of probiotics protected chickens were higher than control birds, and it also increased after probiotic protected chickens following the inoculation of ND vaccine, these results indicated that probiotic could upregulate the expression of IL-7 mRNA in MALT, which improve the MIS response to ND vaccine, and IL-7 maybe one of ways for probiotics improve the humoral immunity. Humoral and cell mediated immune response involve in the protection to against NDV infection [26]. IL-7 is a tissue-derived cytokine secreted from stromal and epithelial cells in various locations, as MALT, bone marrow, thymic stromal cells and keratinocyte, and there are many tumor cells and cords found to secret IL-7, as well $[9,32]$. It was reported $\mathrm{CD} 8^{+} \mathrm{T}$ cell play a role in protection against NDV, and the expression of IL-7 and their receptors have been shown be crucial for $\mathrm{CD}^{+} \mathrm{T}$ cell memory generation and maintenance, moreover, as the only cytokine that has been identified can stimulate memory $\mathrm{CD}^{+} \mathrm{T}$ cell homeostasis and survival, IL-7 play a decisive role in the homeostasis and survival of naiüe $\mathrm{CD}^{+}$and $\mathrm{CD}^{+} \mathrm{T}$ cell in the immune restoration $[12$, 27]. Researchers also found that IL-7 can promote the growth of $\mathrm{B}$ cell, the differentiation and proliferation of pre-B cell, and then $\mathrm{B}$ cells transform into plasma cells after stimulating by antigen to synthesize and secret the Igs [4, 29]. Last but not the least, IL-7 could improve significantly the number of cells which can express typical dendritic cells' mark, and enhance the activity of macrophage cytotoxic factors, and inducing the secretion of cytokines, like interferon (IFN), Tumor necrosis factor (TNF) [3]. IL-7 must be bind to its receptor (IL-7R) that can produce biological effect, and after the combination of IL-7 and IL-7R, there are several signaling pathway be activated, mainly include the Janus Kinase/Signal Transducer and Activator of Transcription (JAK/ STAT) pathway and the Phosphatidylinositol-3-kinase (PI3K)/ AKT pathway, but the mechanism underlying IL-7 mediated signaling pathway in chickens is only partially understood [23].

To sum up, our results demonstrated that probiotics could improve the humoral immunity in respiratory and digestive tracts of chickens, and enhance the immunological response to ND vaccine. The expression of IL-7 mRNA, which probably reflects the humoral immunity of MALT in chickens, and it should have a better synergistic promoting effect on the MIS response to ND vaccine, it may serve as an indicator for the mechanism of probiotics research.

\section{Acknowledgements}

The present study was supported by the National natural science foundation of China (30972162). And we also thank all people from our lab who participated in this program.

\section{References}

[1]. Ainai A, Tamura S-i, Suzuki T, van Riet E, Ito R, et al., (2013) Intranasal vaccination with an inactivated whole influenza virus vaccine induces strong antibody responses in serum and nasal mucus of healthy adults. Human vaccines \& immunotherapeutics 9 (9): 1962-1970.

[2]. Alexander DJ (2009) Report on avian influenza in the Eastern Hemisphere during 1997-2002. Avian Diseases 47 (3): 792-797.

[3]. Alpdogan Ö, van den Brink MR (2005) IL-7 and IL-15: therapeutic cytokines for immunodeficiency. Trends in Immunology 26 (1): 56-64.

[4]. Corfe SA, Paige CJ (2012) The many roles of IL-7 in B cell development; mediator of survival, proliferation and differentiation. Seminars in Immu- nology 24 (3): 198-208.

[5]. Erickson KL, Hubbard NE (2000) Probiotic immunomodulation in health and disease. The Journal of Nutrition 130 (2): 403-409.

[6]. Floch MH, Walker WA, Madsen K, Sanders ME, Macfarlane GT, et al. (2011) Recommendations for probiotic use-2011 update. Journal of Clinical Gastroenterology 45: 168-171.

[7]. Giulietti A, Overbergh L, Valckx D, Decallonne B, Bouillon R, et al., (2001) An overview of real-time quantitative PCR: applications to quantify cytokine gene expression. Methods 25 (4): 386-401.

[8]. Haghighi HR, Gong J, Gyles CL, Hayes MA, Zhou H, et al., (2006) Probiotics stimulate production of natural antibodies in chickens. Clinical and Vaccine Immunology 13 (9): 975-980.

[9]. Hsieh P-f, Liu S-F, Lee T-C, Huang J-S, Yin L-T, et al., (2012) The role of IL-7 in renal proximal tubule epithelial cells fibrosis. Molecular Immunology 50 (1): 74-82.

[10]. Jeurissen SH, Claassen E, Boonstra-Blom AG, Vervelde L, Janse EM (2000) Immunocytochemical techniques to investigate the pathogenesis of infectious micro-organisms and the concurrent immune response of the host. Developmental \& Comparative Immunology 24 (2): 141-151.

[11]. Jin L, Ho Y, Abdullah N, Jalaludin S (2000) Digestive and bacterial enzyme activities in broilers fed diets supplemented with Lactobacillus cultures. Poultry Science 79 (6): 886-891.

[12]. Kaech SM, Hemby S, Kersh E, Ahmed R (2002) Molecular and functional profiling of memory CD8 T cell differentiation. Cell 111 (6): 837-851.

[13]. Kangcheng P (1998) The effect of bacillus licheniformis on humoral immunity in weaned rabbits. Chinese Journal of Microbiology 10(4): 204-206.

[14]. Kapczynski DR, Afonso CL, Miller PJ (2013) Immune responses of poultry to Newcastle disease virus. Developmental \& Comparative Immunology 41 (3): 447-453.

[15]. Kukkonen K, Nieminen T, Poussa T, Savilahti E, Kuitunen M (2006) Effect of probiotics on vaccine antibody responses in infancy-a randomized placebo-controlled double-blind trial. Pediatric Allergy and Immunology 17 (6): 416-421.

[16]. Levy Y, Sereti I, Tambussi G, Routy J, Lelievre J, et al., (2012) Effects of recombinant human interleukin 7 on T-cell recovery and thymic output in HIV-infected patients receiving antiretroviral therapy: results of a phase I/ IIa randomized, placebo-controlled, multicenter study. Clinical Infectious Diseases 55 (2): 291-300.

[17]. Lum JJ, Schnepple DJ, Nie Z, Sanchez-Dardon J, et al., (2004) Differential effects of interleukin-7 and interleukin-15 on NK cell anti-human immunodeficiency virus activity. Journal of Virology 78 (11): 6033-6042.

[18]. Ma YL, Xu ZR (2004). Research advancement of intestinal mucosal immunity.. China Animal Husbandry and Veterinary Medicine 31(2): 27-29.

[19]. Mazzucchelli RI, Riva A, Durum SK (2012) The human IL-7 receptor gene: deletions, polymorphisms and mutations. Seminars in Immunology 24 (3): 225-230.

[20]. Messaoudi S, Manai M, Kergourlay G, Prévost H, Connil N, et al., (2013) Lactobacillus salivarius: bacteriocin and probiotic activity. Food Microbiology 36 (2): 296-304.

[21]. Milne CD, Paige CJ (2006) IL-7: a key regulator of B lymphopoiesis. Seminars in Immunology 18 (1): 20-30.

[22]. Ng S, Hart A, Kamm M, Stagg A, Knight S (2009) Mechanisms of action of probiotics: recent advances. Inflammatory Bowel Diseases 15 (2): 300-310.

[23]. Niu N, Qin X (2013) New insights into IL-7 signaling pathways during early and late $\mathrm{T}$ cell development. Cellular and Molecular Immunology 10 (3): 187-189.

[24]. Ohland CL, MacNaughton WK (2010) Probiotic bacteria and intestinal epithelial barrier function. American Journal of Physiology-Gastrointestinal and Liver Physiology 298 (6): 807-819.

[25]. Pitman RS, Blumberg RS (2000) First line of defense: the role of the intestinal epithelium as an active component of the mucosal immune system. Journal of Gastroenterology 35 (11): 805-814.

[26]. Reynolds D, Maraqa A (2000) Protective immunity against Newcastle disease: the role of cell-mediated immunity. Avian Diseases: 145-154.

[27]. Schluns KS, Lefrançois L (2003) Cytokine control of memory T-cell development and survival. Nature Reviews Immunology 3 (4): 269-279.

[28]. Seal BS, King DJ, Sellers HS (2000) The avian response to Newcastle disease virus. Developmental \& Comparative Immunology 24 (2): 257-268.

[29]. Sekai M, Tani-Ichi S, Yoneyama M, Fujita T, Kina T, et al., (2013) Lymphocyte-stromal cell interaction induces IL-7 expression by interferon regulatory factors. Molecular immunology 54 (3): 378-385.

[30]. Sohail M, Ijaz A, Yousaf M, Ashraf K, Zaneb H, et al., (2010) Alleviation of cyclic heat stress in broilers by dietary supplementation of mannan-oligosaccharide and Lactobacillus-based probiotic: Dynamics of cortisol, thyroid hormones, cholesterol, C-reactive protein, and humoral immunity. Poultry Science 89 (9): 1934-1938.

[31]. Van der Lubben IM, Verhoef JC, Borchard G, Junginger HE (2001) Chi- 
tosan and its derivatives in mucosal drug and vaccine delivery. European Journal of Pharmaceutical Sciences 14 (3): 201-207.

[32]. Ventevogel MS, Sempowski GD (2013) Thymic rejuvenation and aging. Current Opinion in Immunology 25 (4): 516-522.

[33]. World Bank (2011) World livestock disease atlas : a quantitative analysis of global animal health data (2006-2009). Washington, DC

[34]. YANG Y-r, ZHENG S-m, JIANG Y-b, MA C-q (2008) Effects of probiotics with newcastle disease vaccine on the relative content of Igs in local humor of chicks [J]. Journal of Fujian Agriculture and Forestry University (Natural
Science Edition) 3: 17

[35]. Zhao F, Zhang Z, Yao H, Wang L, Liu T, et al., (2013) Effects of cold stress on mRNA expression of immunoglobulin and cytokine in the small intestine of broilers. Research in Veterinary Science 95 (1): 146-155.

[36]. Zhao L, Mei Y, Sun Q, Guo L, Wu Y, et al., (2014) Autologous tumor vaccine modified with recombinant new castle disease virus expressing IL-7 promotes antitumor immune response. The Journal of Immunology 193 (2): 735-745. 